\title{
Implementasi Aplikasi Jejaring Sosial sebagai Alat Bantu Pembelajaran Bahasa Inggris di SMK dan Pondok Pesantren
}

\author{
Eka Widhi Yunarso \\ Fakultas Ilmu Terapan, Universitas Telkom, Bandung, Indonesia \\ Jalan Telekomunikasi, Ters. Buah Batu, Bandung, 40257, Indonesia \\ ekawidhi@tass.telkomuniversity.ac.id
}

\begin{abstract}
Abstrak - SMK Al-Aitaam dan PERSIS Pondok Pesantren merupakan institusi yang bergerak dibidang pendidikan, yang didasarkan pada pendidikan Islam. Pengembangan ilmu pengetahuan, teknologi, bahasa yang sangat pesat saat ini juga mendorong dua lembaga pendidikan untuk memasukkan kurikulum pembelajaran bahasa asing (Inggris) dalam proses pembelajaran yang berjalan di kedua institusi. Tapi pembelajaran yang dilakukan mengalami beberapa masalah seperti kurangnya media yang dinamis belajar bahasa Inggris, yang selalu update, dengan perubahan zaman, kurangnya fasilitas komputer dan media internet yang dapat digunakan oleh siswa untuk menambah kosa kata bahasa Inggris. Untuk mengatasinya hal tersebut diberikan suatu solusi untuk mendukung pembelajaran bahasa Inggris dengan merancang materi pembelajaran meliputi berbagai kompetensi keterampilan terintegrasi yang dapat diakses secara gratis oleh siswa dan guru dalam bentuk aplikasi jejaring sosial yang memungkinkan siswa meningkatkan kemampuan bahasa Inggris mereka dengan menggunakan berbagai fitur yang disediakan, mulai reading, writing dan listening.
\end{abstract}

Kata Kunci - Inggris, Aplikasi Jejaring Sosial, Reading, Writing, Listening

\begin{abstract}
SMK Al-Aitaam and PERSIS boarding school is an institution in the field of education, which is based on Islamic education. Development of science, technology, language very rapidly now also pushing two educational institutions to include the learning of foreign language (English) in the learning process that runs in both institutions. But learning is done having some problems such as the lack of dynamic media to learn English, which is always updated with the changing times, the lack of computer facilities and internet media that can be used by students to augment the English vocabulary. To overcome this it is given a solution to support English language learning by designing learning materials covering a wide range of integrated skills competencies that can be accessed free of charge by students and teachers in the form of a social networking application that allows students improve their English language skills by using a variety of features provided, start reading, writing and listening.
\end{abstract}

Keywords - English, Social Networking Applications, Reading, Writing, Listening

\section{PENDAHULUAN}

SMK Al-Aitaam dan Pondok Pesantren PERSIS merupakan suatu wadah yang bergerak dibidang pendidikan, yang berpedoman pada pendidikan Agama Islam. Perkembangan Ilmu Pengetahuan, Teknologi, Bahasa yang sangat pesat saat ini pun mendorong dua lembaga pendidikan tersebut untuk memasukkan pembelajaran bahasa asing (bahasa Inggris) dalam kurikulum atau pedoman proses pembelajaran yang berjalan di dua lembaga tersebut. Akan tetapi pembelajaran yang dilakukan menemui beberapa permasalahan seperti kurangnya media pembelajaran bahasa Inggris yang dinamis, yang selalu terbarui oleh perkembangan jaman, minimnya sarana komputer maupun media internet yang dapat digunakan oleh siswa untuk menambah kosa kata bahasa Inggris. Perkembangan TIK juga mendorong munculnya situs-situs jejaring sosial yang menghubungkan pengguna dengan pengguna yang lain dalam bentuk pertemanan. Fitur yang diberikan pun menggunakan bahasa Inggris, sehingga mengharuskan para pengguna untuk setidaknya mempelajari bahasa Inggris. Adanya fitur komunikasi baik melalui chat maupun komentar dapat dimanfaatkan sebagai salah satu media pembelajaran bahasa Inggris.

Tujuan dari penelitian ini adalah bagaimana memberikan sebuah solusi dalam mendukung proses pembelajaran bahasa Inggris dengan mendesain materi pembelajaran yang mencakup berbagai ketrampilan kompetensi yang terintegrasi (intergrated skills competency) yang bisa diakses secara gratis (free) oleh para siswa dan guru dalam bentuk berupa aplikasi jejaring sosial yang memungkinkan para siswa meningkatkan kemampuan bahasa Inggrisnya 
dengan menggunakan berbagai fitur yang disediakan, mulai penguasaan reading [1], writing [2] maupun listening [3].

Ada beberapa tinjauan pustaka yang digunakan dalam mendukung penelitian ini, antara lain.

(1) Bahasa Inggris adalah Bahasa Asing yang dianggap penting diajarkan untuk tujuan penerapan dan pengembangan ilmu pengetahuan, teknologi, dan seni budaya, serta pengembangan hubungan antar bangsa [4].

(2) Jejaring sosial adalah suatu struktur sosial yang dibentuk dari simpul-simpul (yang umumnya adalah individu atau organisasi) yang diikat dengan satu atau lebih tipe relasi spesifik seperti nilai, visi, ide, teman, keturunan dll [5].

(3) Data Flow Diagram (DFD) adalah sebuah representasi grafik dari sebuah system yang digunakan untuk menjelaskan aliran dan transformasi data yang bergerak dari pemasukan data hingga ke keluaran. DFD menggambarkan komponen-komponen sebuah sistem, aliran-aliran data di mana komponenkomponen tersebut, dan asal, tujuan dan penyimpanan dari data tersebut [6] [7].

(4) ER Diagram merupakan suatu model untuk menjelaskan hubungan antar data dalam basis data berdasarkan objek-objek dasar data yang mempunyai hubungan antar relasi. ERD digunakan untuk memodelkan struktur data dan hubungan antar data, untuk menggambarkannya digunakan beberapa notasi dan symbol [8].

(5) PHP (atau resminya PHP:Hypertext Preposessor) adalah skrip bersifat server-side yang ditambahkan ke dalam HTML. PHP sendiri merupakan singakatan dari Personal Home Page Tools. Skrip ini akan membuat suatu aplikasi dapat diintegrasikan ke dalam HTML, sehingga suatu halaman web tidak lagi bersifat statis, namun menjadi bersifat dinamis [8].

\section{METODOLOGI PENELITIAN}

Analisa dan pemodelan aplikasi menggunakan metode terstruktur, dengan DFD sebagai pemodelan sistem dan ERD sebagai pemodelan basis data.

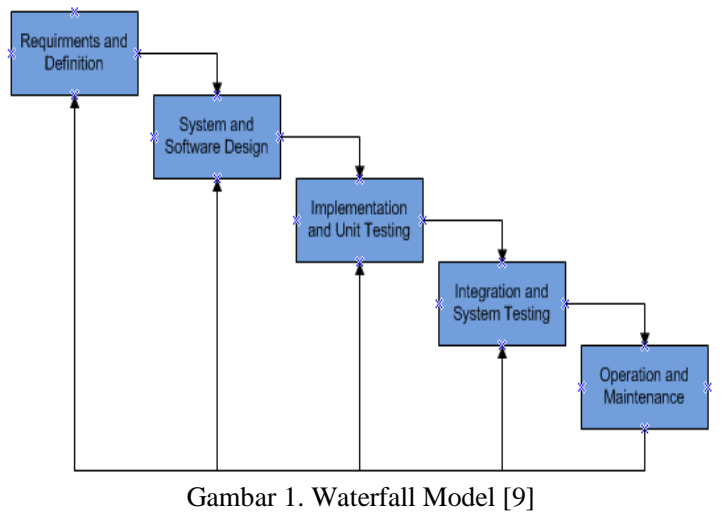

\section{HASIL DAN PEMBAHASAN}

A. Analisis Kebutuhan Sistem

(1) Analisis Kebutuhan Fungsional Sistem, terdapat beberapa fungsi yang harus dibuat, seperti: fungsionalitas login; registrasi pengguna baru; fungsionalitas pertukaran informasi melalui komentar; fungsionalitas chat antar pengguna; English learning and practice; membantu teman dalam proses learning and practice (Help Others).

(2) Analisis Pengguna, pengguna yang menggunakan aplikasi ini merupakan pengguna/masyarakat yang ingin meningkatkan kemampuan /keterampilan berbahasa inggrisnya. Pengguna disini adalah pengguna umum, tidak dibatasi umur, kewarganegaraan, dan pendidikan.

(3) Gambaran Umum Sistem, untuk menjalankan aplikasi ini pengguna diharuskan terdaftar sebagai anggota. Dimana user ini adalah user biasa, yang bisa melakukan login setelah melakukan registrasi, learn and practice, mengelola teman, dan lain-lain yang terdaftar di analisa pengguna user. Content pembelajaran Bahasa Inggris yang aka digunakan dilampirkan di laporan ini.

(4) Kebutuhan Perangkat Keras, berikut adalah spesifikasi kebutuhan perangkat keras yang diperlukan dalam pembuatan aplikasi jejaring sosial untuk pembelajaran bahasa Inggris.

Tabel 1. Spesifikasi Minimum Perangkat Keras

\begin{tabular}{cl}
\hline No & \multicolumn{1}{c}{ Minimum Hardware Specification } \\
\hline & \multicolumn{1}{c}{ CPU Server } \\
2 & Prosesor 2.13 Ghz L2 Chace 4 MB \\
3 & 4 GB RAM GB Hard disk space \\
& $\quad$ CPU Client \\
1 & Intel Pentium 4 \\
2 & 256 MB RAM \\
\hline
\end{tabular}

(5) Kebutuhan Perangkat Lunak, berikut adalah spesifikasi kebutuhan perangkat lunak yang diperlukan dalam pembuatan aplikasi jejaring sosial untuk pembelajaran bahasa Inggris.

Tabel 2. Spesifikasi Minimum Perangkat Lunak

\begin{tabular}{cl}
\hline No & \multicolumn{1}{c}{ Minimum Software Specification } \\
\hline 1 & \multicolumn{1}{c}{ CPU Server } \\
2 & Operating System (Windows, Linux, others) \\
3 & Apache versi 2.2 .4 \\
4 & PHP 4.0 \\
& My Sq1 2.10.2
\end{tabular}

\section{CPU Client}

1 Operating System (Windows, Linux, others) 


\begin{tabular}{ll}
\hline No & \multicolumn{1}{c}{ Minimum Software Specification } \\
\hline 2 & Browser supports javascript and HTML5 (Mozilla \\
. & Firefox, Chrome, others) \\
\hline
\end{tabular}

\section{B. Perancangan}

(1) Perancangan ER Diagram, berikut adalah desain ER Diagram dari pembuatan aplikasi jejaring sosial untuk pembelajaran bahasa Inggris. Dalam desain diagram konteks di bawah ini, terdapat 12 (dua belas) entitas yaitu bab, add, ask, chat, comment, complain, do, do2, learn, message, practice, user.

(2) Perancangan Diagram Konteks, berikut adalah desain Data Flow Diagram (DFD) dari pembuatan aplikasi jejaring sosial untuk pembelajaran bahasa Inggris. Dalam desain diagram konteks di bawah ini, terdapat 2 (dua) sumber dan/atau tujuan data (external entitas) dan 1 (satu) proses utama.

(3) Perancangan DFD Level 1, Diagram konteks kemudian didekomposisi menjadi DFD Level 1 yang menggambarkan proses apa saja yang disediakan oleh aplikasi jejaring sosial untuk pembelajaran bahasa Inggris. Dalam DFD Level 1 terdapat 9 (sembilan) proses, 2 (dua) entitas dan 12 (dua belas) data store.

\section{Implementasi}

Pada implementasinya aplikasi jejaring sosial untuk pembelajaran bahasa Inggris, akan dipakai oleh dua golongan yaitu administrator dan pengguna. Adapun terdapat perbedaan dan hubunganya secara langsung dapat dilihat dari fungsi- fungsi yang ada didalam aplikasi ini.

Fungsionalitas yang dapat dilakukan oleh administrator aplikasi jejaring sosial untuk pembelajaran bahasa Inggris antara lain mengelola data pengguna, mengelola data pembelajaran dan mengelola komplain pengguna. Fungsionalitas yang diberikan pada akun pengguna diantaranya mengolah pesan, mengelola teman, chat, kontribusi, belajar dan latihan. Berikut adalah beberapa implementasi tampilan antar muka.

Gambar 5 merupakan implementasi tampilan beranda pada aplikasi jejaring sosial untuk pembelajaran bahasa Inggris. Tampilan tersebut digunakan oleh pengguna yang ingin menggunakan aplikasi jejaring sosial, diawali dengan melakukan registrasi untuk mendapatkan username dan password.

Gambar 6 merupakan implementasi fungsionalitas mengelola teman pada aplikasi jejaring sosial untuk pembelajaran bahasa Inggris. Dengan menggunakan fungsionalitas tersebut, pengguna dapat melakukan penambahan teman maupun menghapus pertemanan.

Gambar 7 merupakan implementasi fungsionalitas learning and practice pada aplikasi jejaring sosial untuk pembelajaran bahasa Inggris. Dengan menggunakan fungsionalitas tersebut, pengguna dapat melakukan proses pembelajaran bahasa Inggris mulai penguasaan reading, writing maupun listening

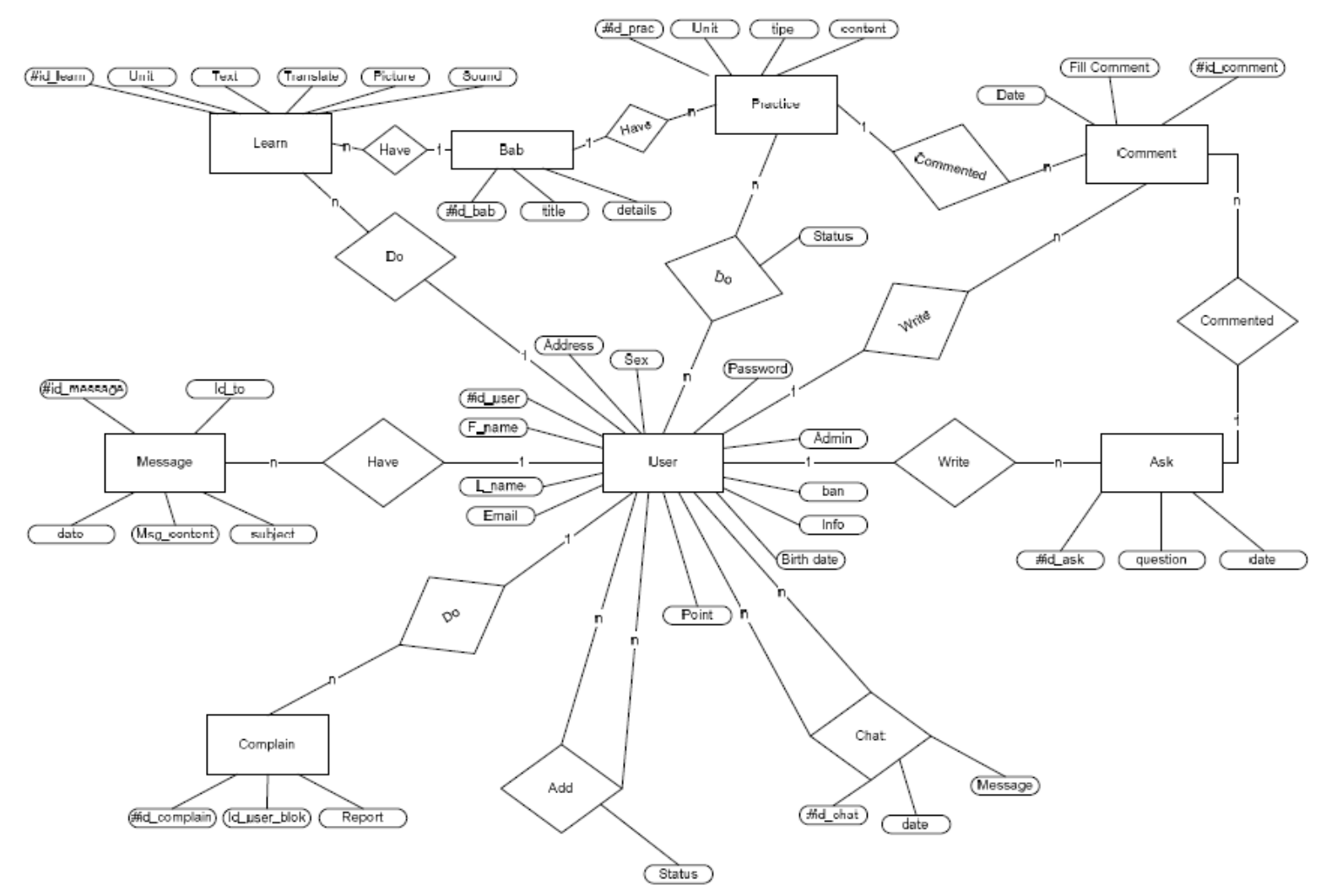

Gambar 2. ER Diagram Aplikasi Jejaring Sosial 


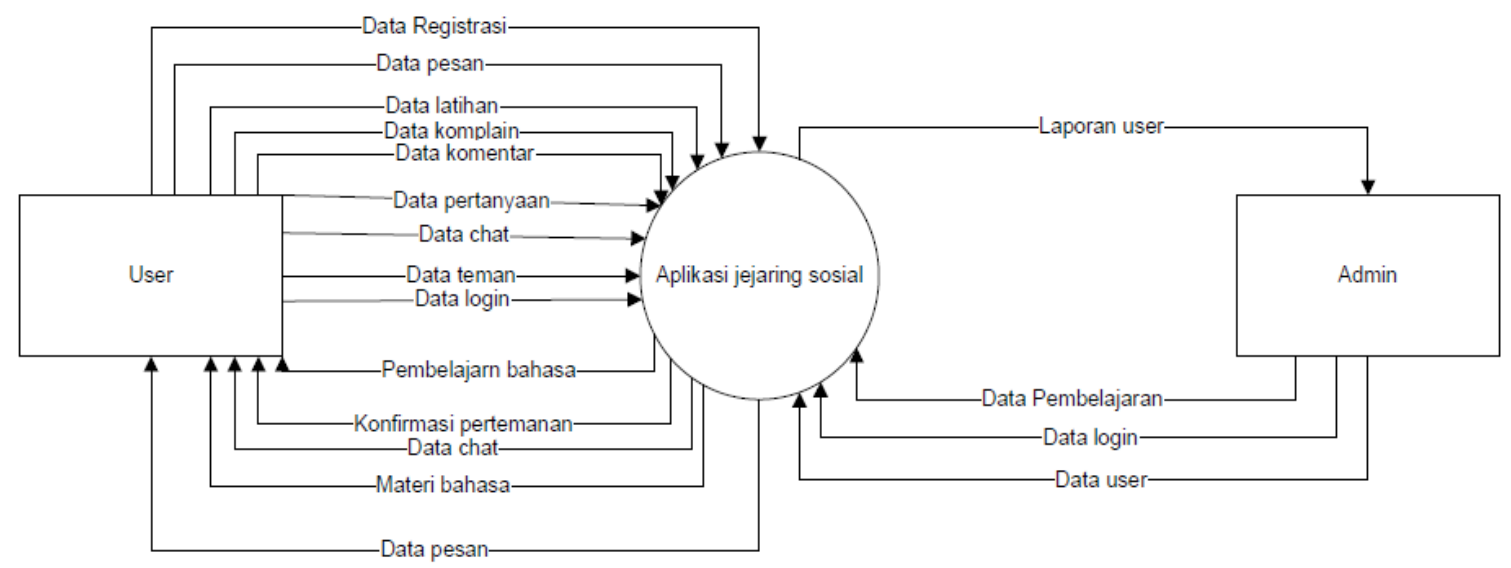

Gambar 3. Context Diagram Aplikasi Jejaring Sosial

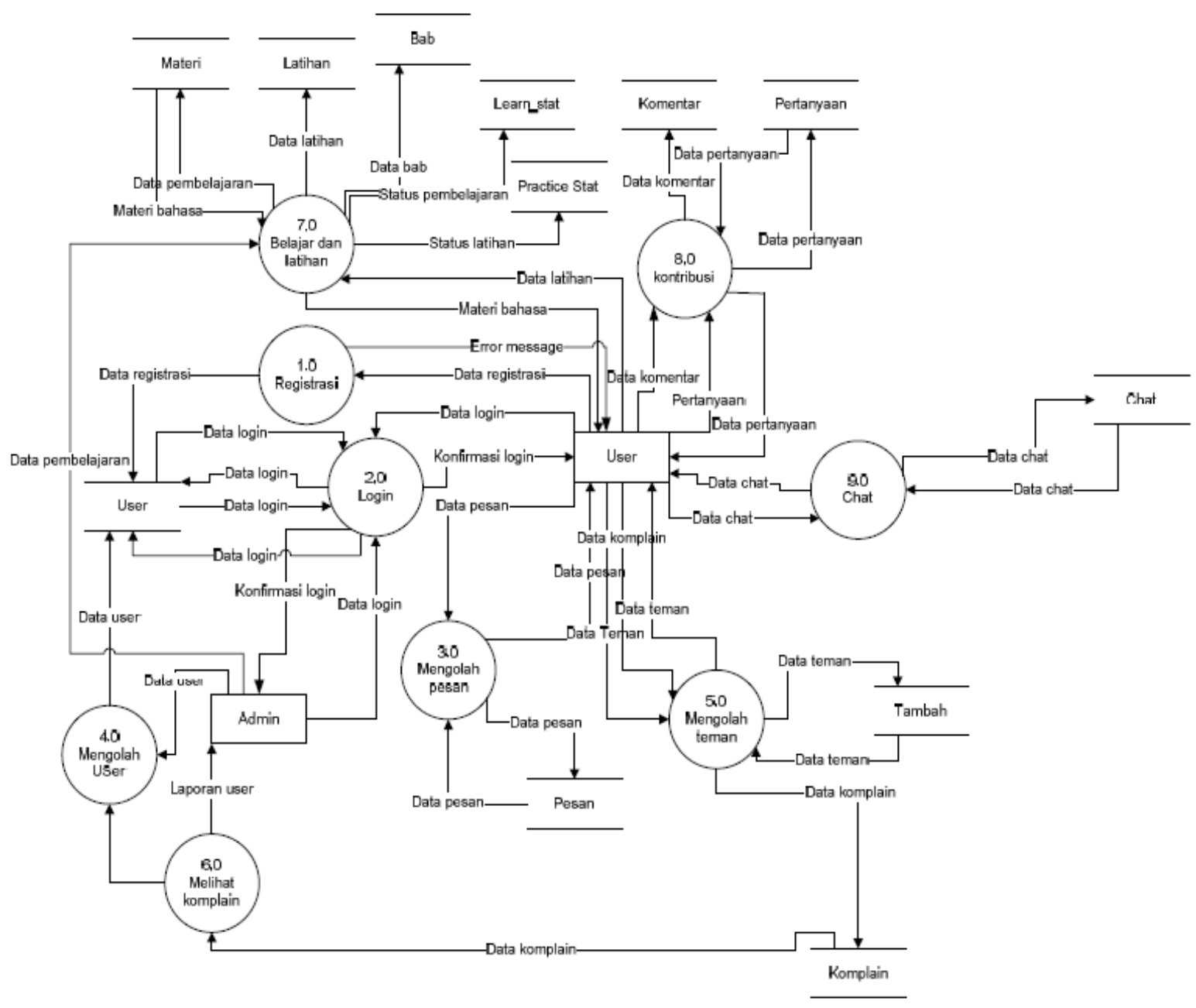

Gambar 4. DFD Level 1 Aplikasi Jejaring Sosial 

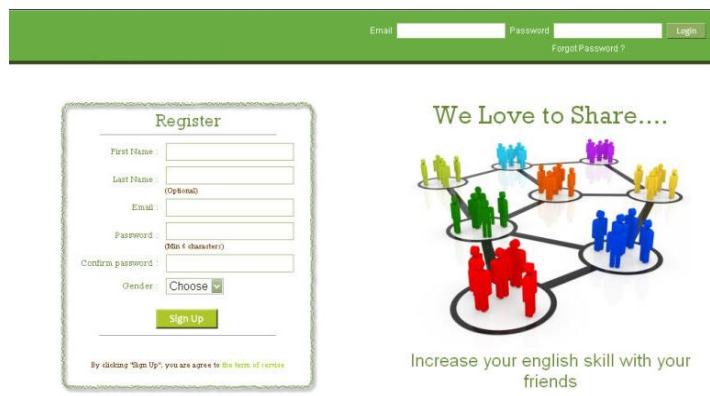

Gambar 5. Tampilan Beranda Aplikasi Jejaring Sosial

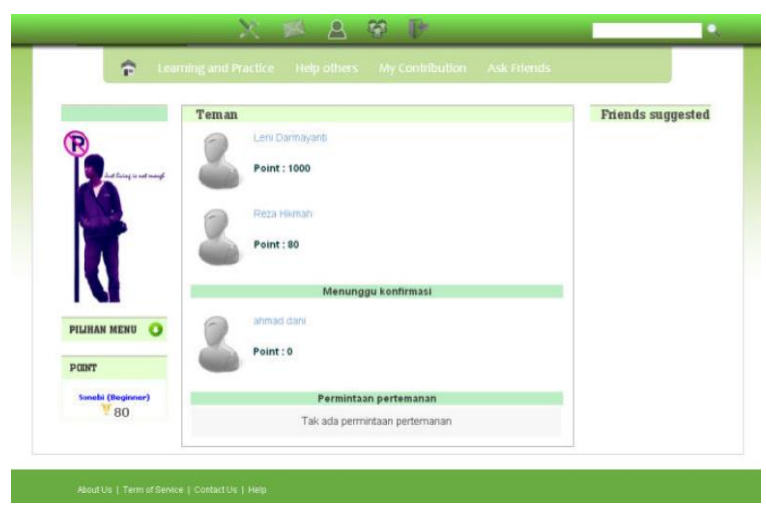

Gambar 6. Tampilan Fungsionalitas Mengelola Teman

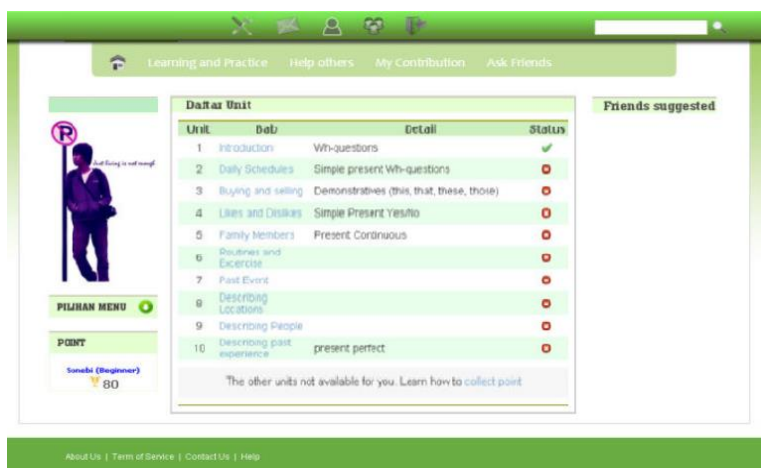

Gambar 7. Tampilan Fungsionalitas Learning and Practice Aplikasi Jejaring Sosial

\section{Pengujian}

(1) Pengujian fungsional dan sistem yang menggunakan teknik pengujian blackbox, penguji menguji desain tingkat tinggi dan kebutuhan pengguna aplikasi spesifikasi untuk merencanakan uji kasus untuk memastikan kode melakukan apa yang dimaksudkan untuk dilakukan. Uji fungsional melibatkan memastikan bahwa fungsi yang ditetapkan dalam spesifikasi kebutuhan bekerja. Pengujian sistem melibatkan menempatkan program baru dalam lingkungan yang berbeda untuk memastikan program itu bekerja pada kelompok pengguna aplikasi yang khas dengan berbagai versi dan jenis sistem operasi dan / atau aplikasi. Pengujian sistem pengujian yang dilakukan pada sistem, lengkap terpadu untuk mengevaluasi kepatuhan sistem dengan persyaratan yang ditentukan [10].

(2) Acceptance testing, setelah pengujian fungsional dan sistem, produk dikirimkan ke pengguna aplikasi dan pengguna aplikasi menjalankan blackbox acceptance tests berdasarkan harapan mereka fungsi tersebut. Acceptance testing adalah pengujian formal dilakukan untuk menentukan apakah atau tidak sistem memenuhi kriteria penerimaannya (kriteria sistem harus memenuhi untuk diterima oleh pengguna aplikasi) dan untuk memungkinkan pengguna aplikasi untuk menentukan apakah atau tidak untuk menerima sistem [10]. Tes ini sering ditentukan oleh pengguna aplikasi dan diberikan kepada tim uji untuk menjalankan sebelum mencoba untuk memberikan produk. Pengguna aplikasi berhak untuk menolak pengiriman perangkat lunak jika uji kasus penerimaan tidak lulus.

Berikut adalah beberapa contoh pengujian secara blackbox yang dilakukan terhadap aplikasi jejaring sosial untuk pembelajaran bahasa Inggris, yang terdapat pada Tabel 3 dan Tabel 4 .

Tabel 3. Pengujian Fungsionalitas Registrasi Pengguna

\begin{tabular}{cllll}
\hline No & & \multicolumn{1}{c}{ Input } & \multicolumn{1}{c}{ Expected } & \multicolumn{1}{c}{ Result } \\
\hline 1 & Data filled in completely and correctly & Register successfully & Register berhasil & Valid \\
2 & Filled with incorrect data, such as writing the wrong email & Failed to Register & Failed to Register \\
3 & Not filled at all & Failed to Register & Failed to Register & Valid \\
4 & To confirm the password is not the same & Error message & Error message \\
appears & appears & Valid &
\end{tabular}

Tabel 4. Pengujian Fungsionalitas Mengelola Komentar

\begin{tabular}{rllll}
\hline No & \multicolumn{1}{c}{ Input } & \multicolumn{1}{c}{ Expected Result } & \multicolumn{1}{c}{ Result n } & Conclusion \\
\hline 1 & Not Filled & Failed insert & Failed insert & Valid \\
2 & Data filled in correctr & Successfully insert & Successfully insert & Valid \\
3 & Filled more than 200 letters & Failed insert & Failed insert & Valid \\
\hline
\end{tabular}




\section{PENUTUP}

\section{A. Kesimpulan}

Hasil akhir dari penelitian ini adalah sebuah aplikasi jejaring sosial untuk pembelajaran bahasa Inggris yang memberikan kemudahan komunikasi dan sebagai media sharing antar pengguna dalam meningkatkan kemampuan bahasa Inggris, dengan menggunakan berbagai fitur yang disediakan, mulai penguasaan reading, writing maupun listening.

\section{DAFTAR PUSTAKA}

[1] J. C. Richards, New Interchange Student's Book 1, New York: Cambridge University Press, 1998.

[2] J. C. Richards, New Interchange Student's Book 2, New York: Cambridge University Press, 1998.

[3] J. C. Richards, New Interchange Student's Book 3, New York: Cambridge University Press, 1998.

[4] Depdikbud, 2011. [Online].
[5] "Social Networking," 2 March 2011. [Online]. Available: http://id.wikipedia.org/wiki/social_networking.

[6] T. DeMarco, Structured Analysis and System Specifications, New York: Prentice Hall, 1979.

[7] E. Yourdon, Modern Structured Analysis, New Jersey: Prentice-Hall International Inc., Englewood Cliffs, 1989.

[8] Y. Kustiyahningsih, Pemrograman Basis Data Berbasis Web Menggunakan PHP \& MySQL, Yogyakarta: Graha Ilmu, 2011.

[9] R. S. Pressman, Software Engineering: A Practitioner's Approach, Singapore: McGraw-Hill, 2006.

[10] IEEE, "IEEE Standard Glossary of Software Engineering Terminology," in IEEE Standard 610.12-1990, 1990. 